\title{
Polska w okolicznościowej poezji rosyjskiej doby pierwszej wojny światowej
}

Jan Orłowski 


\section{Jan Orłowski}

\section{Polska w okolicznościowej poezji rosyjskiej doby pierwszej wojny światowej}

W poezji rosyjskiej - poczynając od schyłku wieku XVIII, a kończąc na czasach nam współczesnych - powstało tak wiele wierszy i poematów na tematy polskie, iż można by złożyć z nich kilkutomową antologię ${ }^{1}$. Polska przykuwała uwagę poetów rosyjskich szczególnie w okresach wojennych konfliktów polsko-rosyjskich, takichjakinsurekcja kościuszkowska, powstanie listopadowe istyczniowe, pierwsza wojna światowa, wojna polsko-bolszewicka roku 1920 oraz kampania wojenna Armii Czerwonej przeciw Polsce po 17 września 1939 roku. Powstałe w tych okolicznościach historycznych rosyjskie wiersze poświęcone sprawom polskim są najczęściej utworami okolicznościowej poezji na użytek propagandowy ${ }^{2}$.

Odmienne przyczyny polityczne skłaniały poetów rosyjskich do tworzenia wierszy o Polsce po drugiej wojnie światowej, ale i w tym okresie najnowszych naszych dziejów owe rosyjskie polonica poetyckie też mogą być w większości przypadków uznane za utwory należące do literatury dydaktyczno-użytkowej. Propagowały one bowiem określone treści ideologiczne, w szczególności zaś opiewano w nich radziecko-polskie braterstwo broni i starano się umacniać sterowaną politycznie przyjaźń polsko-radziecką ${ }^{3}$.

Przed rokiem 1945 - zwłaszcza w latach naszych powstań narodowych — w poezji rosyjskiej pisano o Polsce $z$ wrogością i nienawiścią (przejawy zrozumienia polskich aspiracji niepodległościowych były niezmiernie rzadkie). Wyjątek stanowił początkowy okres pierwszej wojny światowej, szczególnie lata 1914-1915, kiedy to bardzo wyraźnie ujawniły się w Rosji propolskie sympatie, ale i wówczas miały one charakter koniunkturalny, zaś u ich podstaw legły wyraźne intencje

1 Zob. m.in.: Dźwięki kruszonych oków. Polska w poezji rosyjskiej lat 1795-1917, wyb. i opr. B. Białokozowicz, Warszawa 1977; Miecze i galazki oliwne. Antologia poezji rosyjskiej o Polsce (Wiek XVIII-XX), wyb. i opr. J. Orłowski, Warszawa 1995.

2 Zob. J. Orłowski, Z dziejów rosyjskiej poezji propagandowej, „Slavia Orientalis” 1993, nr 3, s. 405-411.

${ }^{3}$ Zob. niektóre wiersze w antologiach: Księga przyjaciót, wyb. i opr. I. Sikirycki, Warszawa 1975; Jak unieš́ wierszem Twoją chwatę. Polska w poezji radzieckiej, wyb. i opr. B. Białokozowicz, Łodź 1977. 
polityczne. Jednakże niektórzy ówcześni myśliciele i poeci — wśród nich Dymitr Mierieżkowski, Wiaczesław Iwanow, Zinaida Gippius, Sergiusz Sołowjow - szczerze pragnęli odrodzenia autonomicznej Polski i pojednania rosyjsko-polskiego. Warto w tym miejscu dodać, iz korzystne zmiany w spojrzeniu Rosjan na tak zwaną „kwestię polską" uwidoczniły się już na początku wieku XX, szczególnie w publicystyce slawisty Aleksandra Pogodina, w prozie Lwa Tołstoja i Włodzimierza Korolenki oraz w poezji Konstantego Balmonta i Apollona Korinfskiego 4

Jednak dopiero pierwsza wojna światowa spowodowała prawdziwą „polonomanię” w literaturze rosyjskiej. Polsce poświęcono wówczas setki utworów poetyckich, szkiców i opowiadań, pisano o niej w niezliczonych artykułach publicystycznych, których treść stanowiły rozważania o jej przyszłości, o wojennych cierpieniach Polaków, o ich walce u boku Rosji przeciw Niemcom i Austrii.

Ten nagły wzrost propolskich nastrojów w Rosji miał określone przyczyny polityczno-wojskowe. Sprzyjał temu wyjątkowy moment historyczny — wojenny konflikt mocarstw zaborczych, które niegdyś dokonały rozbiorów Polski. Obydwaj przeciwnicy wojenni, z jednej strony Niemcy i Austria, z drugiej zaś Rosja, starali się pozyskać dla siebie poparcie Polaków przyjaznymi obietnicami politycznymi. Rosja - jak wiadomo — czyniła to przez ogłoszenie słynnej odezwy naczelnego wodza armii, wielkiego księcia Mikolaja Mikołajewicza, który tak zwracał się do narodu polskiego w dniu 14 sierpnia 1914 roku:

(...) Polacy! Wybila godzina, kiedy najdroższe marzenia waszych ojców i dziadów mogą się ziścić. Półtora wieku temu żywe ciało Polski rozdarto na części, ale jej dusza nie umarła. Żyła ona nadzieją, że nadejdzie godzina zmartwychwstania narodu polskiego i jego braterskiego pojednania z wielką Rosją (...). Jutrzenka nowego życia dla was wschodzi ${ }^{5}$.

W tej odezwie wielkiego księcia zawarta była obietnica, iż pod berłem cara Rosji „zjednoczona zostanie Polska, swobodna w swojej wierze, języku, samorządzie”. Nie było tu więc mowy nie tylko o powstaniu niepodległej Polski, ale nawet o jej autonomii politycznej. Zwraca też uwagę mglistość obietnic, które maskowały metaforyczne sformułowania — „dusza nie umarła”, „nadejdzie godzina zmartwychwstania”, ,jutrzenka nowego życia dla was wschodzi”. Stały się one wyśmienitą pożywką dla rosyjskich poetów, którzy kierowali wówczas do Polaków swoje wierszowane apele.

Jest rzeczą nader charakterystyczną, że w ówczesnych wierszach o Polsce poeci rosyjscy posługiwali się tymi samymi metaforami, jakby dosłownie cytowanymi z proklamacji naczelnego wodza armii. W niektórych utworach poetyckich nawet wprost powolywano się na jego słowa skierowane do Polaków. Niejaki Aleksander Pietrow w wierszu Zmartwychwstanie (Воскресение - mowa w nim właśnie o „zmartwychwstaniu” Polski) pisał w roku 1914:

\footnotetext{
4 Obszernicj problemy te omówionc zostały w pracy: J. Orłowski, $Z$ dziejóu' antypolskich obsesji w literaturze rosyjskiej. Od uieku XVTII do roku 1917, Warszawa 1992.

' Zob. tekst tej odezwy w broszurze: Pro Polonia. Zbiór dokumentów, odezw' glosów prasy europejskiej i osób urybitnych o Polsce i Polakach u' okresie wojny europejskiej, Warszawa 1915, s. 6-7.
} 


\section{Свободы слова прозвучали}

Вождя золотые слова! ${ }^{6}$

Prawie równocześnie Piotr Jurkin w wierszu Do sławnych Polaków (Славным полякам) obwieszczał entuzjastycznie, że odezwa naczelnego wodza armii rosyjskiej znalazła żywy oddźwięk w narodzie polskim:

\section{Жили без дружбы мы долго. Но братья, \\ видим, как чуткивы к словувождя?}

Jak wspomniano, owa odezwa do Polaków zawierała obietnicę zjednoczenia rozdartej Polski po zwycięstwie Rosji nad Niemcami i Austrią. Na język poezji przekładał tę obietnicę Apollon Korinfski, znany jako polonofil i autor kilku wierszy o Polsce, które stworzył po podróży do Warszawy w roku 1908 i następnie w latach pierwszej wojny światowej. W wierszu Do broni! (autor sformułował ten tytuł w języku polskim i wplatał to wezwanie bojowe do każdej strofy tego utworu) Korinfski wspaniałomyślnie obwieszczał:

\section{С Вариавой мы Краков}

И Познань сплотим,

Трех братьев - поляков

В единстве скрепим 8 .

W planach Rosji tak „zjednoczona” Polska miala oczywiście nadal pozostać pod władzą cara. Nie pozostawiała co do tego żadnych wątpliwości sławetna odezwa wysokiego przedstawiciela dynastii Romanowów, pisali też o tym usłużni wobec tronu ówcześni poeci w okolicznościowych wierszach. Niejaki A. Rakszytar ogłosił w roku 1914 buńczuczny wiersz Do Polski (Польщu), w którym przepowiadał rozgromienie Teutonów przez Rosję i zjednoczenie Polski pod berłem carów:

Да будет единая Польиа

Под скипетром русских царей! ${ }^{9}$

Wtórował mu Siemion Nikitin, który w wierszu Pod Warszau'q (Под Bapuaaboü) sławił początkowe zwycięstwa armii rosyjskiej i wyraził radość z tego powodu, że dwugłowy orzeł rosyjski będzie mógł nadal bezpiecznie unosić się nad stolicą Polski:

Иславянский наи реет, какпрежде,

Над Вариавой двуглавый орел ${ }^{10}$.

\footnotetext{
${ }^{6}$ А. Петров, Новые боевые песни, Москва 1914, s. 8-9.

7 П. Юркин, Утро мечты, Петроград 1915, s. 127.

8 „Нива”. Ежемесячные литературные и научно-популярные приложения, 1915, № 2, s. 255-256.

9 А. Ракшитар, Стихопворения поповодуобиеевропейскойвойны 1914а., Выпуск II, Петроград 1914, s. 21.

10 С. Никитин, Святая Русь. Патриомические сmихомворения, Петроград 1915, s. 5.
} 
Warunkiem przyznania Polakom obiecanej w odezwie swobody: wiary, języka i samorządu oraz przyłączenia do „Przywiślańskiego kraju” (podczas wojny 1914-1918 zaniechano w Rosji używania tej nazwy) wyzwolonych ziem zaboru pruskiego i austriackiego był udział żołnierzy polskich w ówczesnej wojnie po stronie Rosji. Dlatego tak gorliwie politycy i publicyści rosyjscy nawoływali Polaków do wspólnej walki przeciw wrogom Słowiańszczyzny. Te wezwania podjęli ochoczo również poeci. Można je znaleźć w bardzo wielu wierszach na tematy polskie. Znany symbolista Konstanty Balmont, który już wcześniej ujawnił swoje propolskie sympatie, ogłosił w roku 1917 wiersz Do Polaków (К полякам), wyraźnie inspirowany polskim hasłem powstańczym „Za wolność naszą i waszą”. Kończył ten utwór następującymi słowami:

Поляки, взнесемте заздравную чашу!

Мы дружно пойдем,

Единым путем,

За нашу свободу и вашу! $!^{11}$

Bojowym zawołaniem „Do broni!” zagrzewał Polaków do walki wspomniany już Apollon Korinfski. Głosił on - podobnie jak Balmont i inni - hasło solidaryzmu słowiańskiego. W wierszowanym apelu Do broni! stwierdzał, że naród polski razem z Rosjanami pójdzie w bój za wspólną „matkę - ojczyznę":

Он - снами опять...

За Бога - do broni!

За родину-мать!

Bardzo reprezentatywnym, niemal wzorcowym utworem ówczesnej rosyjskiej poezji agitacyjnej jest przytoczony już wiersz Aleksandra Pietrowa Zmartwychwstanie, zwłaszcza jego następująca zwrotka $z$ wezwaniem „braci - Polaków” do walki ze wspólnym wrogiem:

\section{Поляки! Заря занялася:}

Воскреснет весь польский народ!

Вся Русь на врагов поднялася -

Так, братья-поляки, вперед!

Autor zebrał w tej strofie najważniejsze hasła, którymi kokietowano Polaków w ówczesnej rosyjskiej propagandzie politycznej. Jest tu więc zapowiedź zmartwychwstania całego narodu polskiego, jest wezwanie do walki u boku Rosji, która wystąpila przeciw wrogom Polski, w końcu autor nazywa Polaków „braćmi”, co jest deklaracją gotowości do pojednania rosyjsko-polskiego i zapomnienia o historycznych waśniach i nienawiści między obydwoma narodami. Motyw „braci-Polaków” i Polski-siostry” (określanej niekiedy jako „młodsza siostra”) powtarzał się zresztą dosyć często u różnych autorów - Włodzimierza Pawłowa, Sergiusza Michajłowa, Walerego Briusowa, Mikołaja Agniwcewa i innych. Ten ostatni w wierszu zatytułowanym akurat Do braci

${ }^{11}$ К. Бальмонт, К полякам, w: Ветвь. Сборник клуба московских писателей, Москва 1917, s. 10. 
Polaków (Братьям-полякам), wzywając ich do „uderzenia na wrogów”, przypominał jednocześnie dawne polskie tradycje rycerskie:

O, дети растерзанной Польии,

Ударьте, как встарь, на врагов!...

Иль может у Польши нет больше

Достойньх Былого сынов? ${ }^{12}$

Motyw „Polski-siostry” najwyraźniej wystąpił w utworach Sergiusza Kopytkina i Tatiany Szczepkiny-Kupernik. Pierwszy z nich poświęcil Polsce kilka wierszy. W jednym z nich (Польиe) przedstawił Polskę jako płaczącą w nieszczęściach wojennych siostrę „potężnego brata”, który ją obroni i zabije wraże „szatańskie nasienie”, czyli jej wrogów:

Не плачь, сестра. Твой брат могучий

Убьет исчадье сатаны1 13 .

W ujęciu Tatiany Szczepkiny-Kupernik Polska była „bliską młodszą siostrą” Rosji, która powinna okazać pomoc jej cierpiącym dzieciom. Oto charakterystyczne fragmenty wiersza Polska (Польиа) tej poetki:

Край нам близкий, Польиа, Польша,

Наша младшая сестра... (...)

ДляроднойиблизкойПольии

Кто что может - пусть дает:

Дайте щедро, дайте больше

Хлеба, ласки и забот ${ }^{14}$.

Na motywie „Polski-siostry” osnuty został też wiersz Sergiusza Sokolskiego Do Polski (Польше). W ujęciu tego poety upersonifikowana Polska określana jest epitetami „żałosna”, „miła”, „pokrzywdzona przez los". Oto mały fragment tej ody do Polski:

Поговоримте мы о Польие,

О нашей горестной сестре.

Поговорим о Польще милой,

Так обездоленной судьбой,

Н скажем ей с душевной слой:

„O, Польша, сердчем мы с тобой!”15.

12 Н. Агнивцев, Под звон мечей, Петроград 1915, s. 101.

13 С. Копыткин, Песни о войне, Петроград 1915, s. 29.

14 Т. Щепкина-Куперник, Отзвуки войны. Стихотворения, Москва 1915, s. 71.

15 С. Сокольский, Пляшуцая лирика. Стихотворения и песни, Петроград 1916, s. 20. 
Zapewnieniom o braterskich uczuciach wobec Polski i wspólczuciu jej w niedoli towarzyszą w tym wierszu Sokolskiego nadzieje, że srogi czas wojny na wieki skuł „miłą siostrę” Polskę z Rosją:

Давайте, скажем ей сердечно:

„O, наиа милая сестра,

Теперь с тобой нас навечно

Сковала лютая пора (...)"

W wierszu Placz panny (Плач naнны) piotrogrodzkiego poety Jurija Wiegowa (właśc. Josif Woronko) Polska przybiera postać dotkniętej nieszczęściami płaczącej panny, którą przygarnie i utuli „kochająca matka Rosja”:

Не плачь, о панна: знай и помни,

Россия-любяцаямать $(\ldots)^{16}$

Błędne byłoby jednak przekonanie, że w okolicznościowej poezji rosyjskiej doby pierwszej wojny światowej pisano o Polsce wyłącznie w sposób życzliwy, pojednawczy i protekcjonalny. Potężny „starszy brat" (pojęcie to, tak dobrze znane Polakom, pojawiło się właśnie wtedy) uzurpował sobie prawo do pouczeń i ostrzeżeń wobec niesfornej „młodszej siostry”. Takie właśnie spojrzenie na Polskę wyraziła Nadieżda Bronicka w wierszu Do Polaków (Do jednej z partii) Полякам. Одной из партий. Otwarcie przestrzegała w nim Polaków przed „separatyzmem” i próbami oderwania się od Rosji:

И не думайте нас победить

Побужденьями сепаратизма:

Равнодуино себя расиленить

Не допустит живая отчизна! ${ }^{17}$

W początkowym okresie wojny nie dopuszczano w Rosji nawet myśli o tym, że może powstać wolna Polska i wyrwać się spod władzy carów. Jest więc rzeczą zrozumiałą, że z wrogością zareagowano tam na skierowaną przeciw Rosji zbrojną działalność Legionów Polskich dowodzonych przez Józefa Piłsudskiego. W publicystyce wyraził to między innymi Walery Briusow, w poezji zaś Nadzieżda Bronicka, Osip Mandelsztam i Maria Morawska (Polski pulk). Mandelsztam w jednym ze swych wierszy tak napisał o „szaleńczym czynie” polskich oddziałów strzeleckich:

\section{Поляки! Яневижусмысла}

В безумном подвиге стрелков! ${ }^{18}$

Według wszelkich reguł wojny psychologicznej rosyjska poezja okolicznościowa lat pierwszej wojny światowej gloryfikowała politykę Rosji, działania armii rosyjskiej, bohaterstwo i prawość

16 „На Берегах Невы”, 1914, № 7-8, s. 3.

${ }_{17}$ Н. Броницкая, Отголоски войны, Петроград 1916, s. 33.

в „Нива” 1914, № 43, s. 833. 
jej żołnierzy oraz starała się różnymi sposobami zohydzić przeciwników - zwłaszcza armię niemiecką. Armie wrogów przedstawiano jako Hunów XX wieku, jako hordy morderców, gwałcicieli i grabieżców, którzy dopuszczają się strasznych zbrodni na zajętych ziemiach Polski $\mathrm{i}$ innych krajów. W licznych wierszach i opowiadaniach opisywano więc wojenną martyrologię narodu polskiego - spalone wsie, zburzone miasta i śmierć ich mieszkańców. Podobne obrazki tworzyli zwłaszcza mało znani, mierni poeci i amatorscy autorzy nieporadnych wierszy, często prości frontowi żołnierze. Oto przykład takiej anonimowej Żotnierskiej pieśni o Polsce (Cолдатская песня о Польще), którą wydrukował ówczesny tygodnik „Ogniwo”:

\section{Был красив тыл и наряден,}

Цвел весною как рай,

A пеперь ты весь разграблен,

Бедный польский край.

Сожжены злостными врагами

Деревни, села, города;

Брапской кровью и слезами

Залитапольскаяземля. $(. .)^{19}$

Tego rodzaju wojenna „poezja” okolicznościowa, obliczona na tanie efekty propagandowe, obficie zapełniała łamy ówczesnych rosyjskich czasopism, stronice almanachów literackich i zbiorów wierszy. Ale oprócz tego zapomnianego dzisiaj masowego wierszoróbstwa powstawały również poświęcone Polsce bardziej ambitne utwory poetyckie, których autorami byli wybitni poeci, wśród nich: Walery Briusow, Konstanty Balmont, Fiodor Sołogub, Zinaida Gippius, Sergiusz Jesienin. Ich wiersze o Polsce powstały wprawdzie w okolicznościach pierwszej wojny światowej, ale trudno byłoby zakwalifikować je jako utwory należące do literatury czysto użytkowej, pisanej na potrzeby bieżącej chwili. Autorzy tych wierszy podejmowali trudne problemy dziejowych waśni rosyjsko-polskich, dostrzegali winy Rosji wobec Polski (Gippius, Sołowjow), sięgali w swoich utworach do motywów polskiej literatury i tradycji narodowej.

Okolicznościowe wiersze poetów rosyjskich na tematy polskie z lat pierwszej wojny światowej były swoistym barometrem nastrojów politycznych w ówczesnej Rosji, szczególnie zaś w odniesieniu do „kwestii polskiej”. Ich ostrze agitacyjne - w zależności od sytuacji na froncie rosyjsko-niemieckim i od postaw Polaków w toczącej się wojnie — mogło być zwrócone przeciwko nim, lub też mogło być użyte w ich obronie, wspierać ich złudne nadzieje na uzyskanie większych swobód po wygraniu wojny przez Rosję.

Okolicznościowe wiersze o Polsce, które tworzyli ówcześni poeci rosyjscy, miały służyć przede wszystkim celom dydaktyczno-agitacyjnym, spełniały więc określoną rolę użytkową. Tego rodzaju utwór wierszowany nie bywa zazwyczaj obliczony na efekt artystyczny, ale ma jednak właściwą sobie poetykę. W zamiarze twórcy ma bowiem oddziaływać przede wszystkim na sferę doznań emocjonalnych odbiorcy. Dlatego operuje zwykle kolorem czarno-białym w opisie „swoich”

19 „Огниво” 1915, № 15, s. 14. 
i „wrogów”. Podmiot mówiący tych wierszy mówi o sobie - „my”, utożsamia się ze zbiorowością, przemawia $\mathrm{w}$ imieniu swojego narodu do innego narodu, jak chociażby w owym wezwaniu Balmonta: „Polacy (...) zgodnie pójdziemy wspólną drogą za naszą wolność i waszą!”.

Omawiane wyżej wiersze rosyjskie o Polsce z lat 1914-1917 ze względu na swoją strukturę gatunkową należą do liryki apelatywnej, swoją formą przypominają najczęściej tradycyjną dziewiętnastowieczną rosyjską lirykę obywatelsko-społeczną. Ale niekiedy nadawano im formę przyśpiewki żołnierskiej, jak o tym świadczy przytoczona niżej anonimowa czastuszka o żołnierzu Waniuszy, który poległ w Polsce:

Не приилось Ванюше дольие

Свою любуику любить,

А пришлось Ванюше в Польше

Буйну голову сложить ${ }^{20}$.

Wiersze znanych poetów odznaczały się formą bardziej wyszukaną. Balmont, Briusow i Jesienin poświęcili Polsce sonety, Korinfski zaś tworzył ballady historyczne o zmaganiach Polaków $\mathrm{i}$ innych narodów słowiańskich $\mathrm{z}$ germańskim naporem.

Ogromna większość rosyjskich wierszy o Polsce z lat pierwszej wojny światowej nie osiągnęła wyżyn sztuki poetyckiej, była pozbawiona chociażby przeciętnych walorów artystyczno-literackich. Owa poezja okolicznościowa spełniała wyznaczoną jej rolę utylitarną, służyła celom dydaktyczno-agitacyjnym. Jej wartość użytkowa mogła się jednak realizować tylko w określonych konfiguracjach politycznych. Kilka lat później w odmiennych już warunkach historycznych, kiedy odrodziła się wolna Polska, te rosyjskie polonica literackie zostały z góry skazane na zapomnienie. Dzisiaj stanowią już tylko interesujące zjawisko kulturowe z pogranicza polityki i socjologii życia literackiego. 